\title{
TEACHING THE HOLY QURAN TO YOUNG LEARNERS (7-12 YEARS OLD)
}

\author{
Andi Irlina \\ English Education Department \\ Universitas Islam Negeri Antasari Banjarmasin \\ J1. A. Yani Km 4,5, Banjarmasin, Kalimantan Selatan, Indonesia \\ Email: andi.irlina23@gmail.com \\ Website: https://jurnal.uin-antasari.ac.id/index.php/adzka \\ Received: Juni 2019; Accepted: Juni 2019; Published: Juni 2019
}

\begin{abstract}
Teaching the holy Qur'an to young learners is very important to keep children healthiness, physically or mentally. Young learner teacher should employ several techniques or methods that interest children. This article explores some methods for teaching the holy Quran to young learner. The teachers should provide the appropriate way, techniques or methods in teaching how to read and how to memorize the holy Qur'an well, appropriate techniques and methods can help children to be able to learn or memorize the holy Qur'an easily such as Baghdadiyah method, Iqra, qiro'ati, albarqy, tilawati, and hambalis method. In teaching recitation and memorization of the Qur'an to young learners the methods are talqin musyafahah and takrir methods, deposited method, and muraja'ah method (repetition).
\end{abstract}

Key Words: teaching; the holy Quran; young learner; children.

\section{INTRODUCTION}

Education has important role in improving the quality of a Nation. Good education can prepare human resources that can fight against other Nation all over the world in every aspect of life, such as economic, politic, and cultural development. Qualified human resources can help the Nation to achieve their success. Therefore, they should be prepared well.

Qualified human resources can be achieved by facilitating good education for human from their early age, even when the infants are still in their mothers uterus. Teaching the holy qur'an for moslem from their early life can help children improving their intelligent and Allah, the Almighty God would always save them. Imam Thabarani, from Ali bin Abi Thalib stated that the messenger of Allah emphasize to teach the holy qur'an to children, because children, or everybody who memorize the holy qur'an always gets protection from Allah, the Almighty God.

Furthermore, in the holy Qur'an it is stated that "dan kami turunkan dari al qur'an sesuatu yang menjadi penyembuh dan rahmat bagi orang-orang beriman." (Al Isra':82). Many Islamic researchers state that listening to the holy qur'an not only improving the quality of human intelligence, but also developing psychic calmness, and faith. Amka (2016:24) states that reading a holy Qur'an can give good effect of the readers body and soul such as give calmness effect; improving creativity; strengthen human body; good concentration; cure many kinds of deseases; give peace situation; reduce brain tension; reduce nervousness; avoid people from fear; strengthen personality and increasing language ability.

The above explanation indicates that teaching the holy Qur'an to young learners is very important to keep children healthiness, physically or mentally. Therefore, family, school, and society environments play important role in achieving the goal of teaching the holy qur'an to young learners. What is the right age to start teaching the holy Qur'an to young learners, then? There is not clear cut age boundary to start with and to finish Qur'an learning. The most important is the way to teach Qur'an to young learners. 
Don Campbell (2002: 18-19, Irlina, 2014: 61) stated that children brain capacity in their early age are generally influenced by condition and situation around them. Whatever they hear, listen, touch, feel, or elsewhere will influence the development and the capacity of their brain. Therefore, adult who live around children must aware about this that they can help young learners to achieve optimal results in their physical and mental development by giving them appropriate ways or techniques in teaching and memorizing the holy Qur'an.

To acquire optimal multiple intelligence of children, such as spiritual intelligence, emotional intelligence, social intelligence, intellectual intelligence and kinesthetic or physical intelligence, children should use their left and right hemisphere equally. This can be achieved by teaching them the holy Qur'an in their early age with appropriate methods or techniques.

To apply appropriate methods and techniques in teaching the holy Qur'an to young learners, a teachers of young learners should know the characteristic of young learners. The teachers who know young learners characteristic will find it easy and enjoyable working with the children because they have the chance of becoming child again, of seeing the world through a child eyes. Rasulullah (sallallahu alayhi wasallam) said: "the best of you are those who learn the Qur'an and teach it (Bukhari vol 6-61: 545).

Some experts explain about young learners in similar point of view. As Kasihani (2007) in Irlina (2011, p. 2-3) define young learners as children aged between six (6) to thirteen (13) years old. Rixon (1999), in Irlina (2011. P.3) defines young learners as children between 5 years old to 12 years old. Purwaningsih in Irlina, (2011, p.3), states that young learner are learner in Elementary School aging 9-10 years old who are learning English as a foreign language. Young learners according to the writer here are children who study at play group, kindergarten, and elementary school. Children aged between three (3) to twelve (12) years old. Generally, young learners have characteristics such as like moving (they cannot be silent); like imitating everything; like argue at something; cannot differentiate between the right and the wrong one; like asking questions; memory is excellent; like playing; lake to be motivated (or target reward); like competition; like using their imagination; tend to have skill; can easily to acquire a new language; like puzzle and sensitive (Mursi, 2001, p. 10-16).

Young children learn differently from older children, adolescents and adults in several ways like respond to meaning even if they do not understand individual words and often learn indirectly rather than directly. That is they take in information from all sides, learning from everything around them rather than only focusing on the precise topic they are being taught. Then, their understanding comes not just from explanation, but also from what they see and hear, and crucially have a chance to touch and interact with. They generally display an enthusiasm for learning and a curiosity about the world around them. They have a need for individual attention and approval from the teacher. They are keen to talk about themselves, and respond well to learning that uses themselves and their own lives as main topics in the classroom. They have a limited attention Span, unless activities are extremely engaging. They can easily get bored, losing interest after ten minutes or so (Harmer, 2001, p. 38).

The above statements demand young learner teacher to employ several techniques or methods that interest children. The teacher must prepare indoor and outdoor techniques or methods effective and joyful for young learners. Lots of short, simple activities are best suited to their attention span. Presenting some appropriate techniques or methods to read and to memorize the holy Qur'an to young learners can help them to be able to read and memorize the holy Qur'an faster and enjoyable.

\section{RESEARCH METODOLOGY}

This is literature review with qualitative approach. Object of this research is what kind of appropriate way, techniques or methods in teaching how to read and how to memorize the holy Qur'an for young learner. The method of data collection is library research. The data 
obtained is compiled, analyzed, and then acquired conclusions about the method for teaching the holy Qur'an for young learners.

\section{RESEARCH FINDING AND DISCUSSION}

\section{Methods and Techniques in Teaching the Holy Qur'an to Young Learners}

Teaching a holy Qur'an to young learners should be fun. Do not teach the Qur'an to young children in a strict manner. A Qur'anic teacher should treat the young learners with love, respect, firmness, and gentleness. Amka states that there are at least five methods can be used in teaching Qur'an to young learners. The methods are; baghdadiyah method, iqro method, qiro'ati method, al Barqi method and tilawati method. (Amka, 2016:120-123).

a. Baghdadiyah method

This method derives from Bagdad. It was developing since the period of Bani Abbasiyah. This method is very familiar for Indonesian people, since it has been used for Indonesian for centuries. Indonesian calls this method as "metode eja". The application of the method beginning from the easiest to the most difficult one, from concrete to abstract, and from general to specific ones.

Much superiority can be found in Baghdadiyah method, among them are the materials are designed systematically; the central theme focusing on the $30^{\text {th }}$ Arabic alphabet; the sound patterns and alphabet arrangement are arranged in orderly fashion; spelling method used to teach is quite interesting for young learners; tajweed is integrated in each reading; juz amma is put previously.

b. Iqra' method

This method is compiled by ustadz As'ad Human from Kota Gede, Yogyakarta. It consists of 6 chapters. This method is very popular for young learners, especially, children of kindergarten and elementary schools. There are some characteristics of Iqra' differ from others, among them are every chapter is supplemented with the way to teach it; the instruction of chapter one is the same as the instruction of other chapters; the strategy uses direct reading; after introducing the Arabic alphabet the teacher can directly teach the learners "huruf sambung"; it has been conditioned with the holy Qur'an; it is completed with tajweed.

c. Qiro'ati method

This is a simple method in learning a holy Qur'an. It consist of 6 chapters. It was published in July $1^{\text {st }} 1986$, when the TK Al Quran established the first time in Indonesia. Qiroati method is compilled by H. Dachlan Salim Zarkasyi. This method explain essential material. It begins with introducing the alphabet of Hijaiyah and a systematic alphabet in written form

d. Al-Barqy method

Al Barqi method has been developed by a lecturer of Adab Faculty, IAIN Sunan Ampel Surabaya, Muhadzir Sulthan in 1965. The research result of department of religion at the time explained that this method can be implemented for children, teenagers and adult as well. The superiority of this method are the teacher can teach the holy Qur'an simply and practically; it does not need much time to learn it; and it only use one book.

e. Tilawati method

Tilawati method was compiled by a team involving Drs. H. Hassan Sadzili and Drs. H. Ali Muaffa, at all. This method use right hemisphere dominantly since the way to teach the holy Qur'an artisticly. The characteristic of this method are the approach use classical and individual in balance; this method is arranged simply that the learners can easily to study it; it focuses on the way the learners read the qur'an "secara tartil"; it uses variety of tilawah that avoid learners from feeling bored and this method uses listening system that the learners can correct other learners mistakes or mispronounce. 


\section{f. Hambalis method}

Hambalis method is a method created by the writer. It is a method that is appropriated for young learners aged between two to six years old. Hambalis is the abbreviation of "hafalkan, main, baca, dan tuliskan". This method has been introduced to the children of free school learners of Al Mansyur Kotabaru regency since 2014. This method is very effective that most of the children were able to read a holy qur'an in a short time. Technique in presenting the Hambalis method are introduce the Arabic alphabet by singing them; reciting the Arabic vocabularies; memorizing short verse of the Qur'an; prepare chart or picture of Arabic alphabet, play them with the young learners; ask the young learners to color the alphabet and the words as well; tell them to read from the simplest to the most difficult one; ask the learners to thicken the Arabic alphabet, and Arabic words as well.

\section{Methods and Techniques of Teaching Recitation and Memorization of Qur'an to Young Learners}

There are many kinds of methods that can be used in teaching recitation and memorization of the Qur'an to young learners. Theoretically, the following methods the can be used.

a. Talqin Musyafahah and Takrir methods

To apply this method, a teacher presents the lesson by reading it, and the learners listen to it directly. The teacher does not use a text, but he/she only memorize the lesson as well. If the teacher writes something, it only to remain him/her from the learners mistakes. Musyafahah also used to see the teachers lips to know the appropriate sounds of the Arabic alphabet. Blind people usually use this technique to memorize the qur'an because this method does not need to read, the learners need only good listening and concentration.

\section{b. Deposited Method}

Deposited method is a method that is used by the learners in increasing the quality and the quantity of the learners memorization. The learners qur'anic memorization is reciting the qur'an in each surah after memorizing it in front of the teacher individually. According to Abdurrahman Abdul Khaliq (2008:119-121), there are some techniques al qur'anic memorizers can use in improving the quality of their memorization of al Qur'an. The techniques could be a learner should control him/herself the way to memorize al Qur'an, they do not need to memorize the Qur'an in the large portion once in a time; ascertain what day they memorize the Qur'an and what day they would repeat it; not allowed to memorize another verse before the verse being memorized learnt by heart well; always recite the holy qur'an after completing memorizing it; begin to memorize the Qur'an in his/her early life.

c. Muraja'ah Method (repetition)

Muraja'ah means a learner or those who memorize the Qur'an recheck their memorization totally. In this case, a learner individually repeat all of surah has been memorized in a month, in the last two or three month, even in a year. This kind of technique had been done by the prophet Muhammad, p.buh in front of angel Gabriel every year. The same technique had been done by the prophet best friends for generations (Rudi Hartono, 2006: 33). Raghib As-Sirjani (2008: 79-82) further stated that there are some strategies can be applied in presenting muraja'ah method, such as read the holy Al-Qur'an most of the time; repeat to listen to the holy Qur'an that has been memorized through media, like tape recorder, hand phone, or other recording; read surah or the verse that had been memorized when you are praying; and recite the verse artistically.

In addition Raghib As-Sirjani (2008: 86-115) explained that there are many ways that can support the learners in memorizing Al-Qur'an as in the following statement to prepare a good planning and make a group. The statements assigned that the learners can actively memorize the holy Qur'an effectively. This is due to the way the learners of al Qur'an should 
behave in learning Allah's Book. The ways are take al Qur'an whenever and wherever you are; to begin to memorize al Qur'an, a learner should begin from the simple verse to the complicated one; the long verse should be divided into part, so that the learners can easily memorize it; focusing our attention to mutasyabihat verse; build a competition in memorizing Al-Qur'an

Another method that can good to apply in teaching memorization of the Qur'an to young learners is each learner should be assigned a mushaf that will be especially his. He should be required to bring it with him every day and to respect and care for it. Be sure that the learners are always come to the class on time. The learners should be assigned daily to the hifz school at least four hours. The largest number of students in each class is 20. Each learner should be asked to prepare three daily assignments; one of which will be done at home and the rest is in the mosque or in the classroom (madinahquran academy.com/methodology-ofteaching-quran-recitation-memorizatin, accessed on $20^{\text {th }}$ August 2017, at 10.p.m).

Many kinds of methods have been discussed above. Each has its own superiority and shortcoming. What the writer has to emphasize here that whatever the methods and the technique are, the successful learners or teachers are those who learn and teach al Qur'an calmly, patiently and sincerely. Because Allah, The Almighty God is always with everybody who learn and teach al Qur'an. Also Allah, The Almighty God sent al Qur'an to His Messenger, The prophet Muhammad, P.buh as "Rahmatan Lil Alamin". Allah, The Almighty God says in al Qur'an as follow: "Kami tidak menurunkan al Qur'an ini kepadamu (Muhammad) agar Engkau menjadi susah, melainkan sebagai peringatan bagi orang yang takut kepada Allah swt (Q.S.Thaha: 2-3).

\section{CONCLUSION}

Teaching the holy Qur'an to young learners needs appropriate techniques. The techniques should be suitable to the children life. Young learners learn more rapidly than older ones and adult learners. However, teachers of young learners must realize the young learner's characteristics in learning. In general, children like to learn new things, playing, learning by doing, singing and learning something in short time. Therefore the teachers should provide the appropriate way, techniques or methods in teaching how to read and how to memorize the holy Qur'an well, appropriate techniques and methods can help children to be able to learn or memorize the holy Qur'an easily.

\section{REFERENCES}

Aziz, Amka Abdul. (2016). Membumikan Al-Qur'an di Sekolah, Sidoarjo, Nizamia Learning Center.

Az-Zabidi, Imam. (2002). Ringkasan Hadis Shahih Al-Bukhari, Jakarta, Pustaka Amani.

Echols, John M, at all., (1989). Kamus Indonesia Inggris, Jakarta, PT Gramedia.

M.A, Mansur. (2005). Pendidikan Anak Usia Dini dalam Islam, Yogyakarta, Pustaka Belajar.

Rah.a, Maulana Muhammad Zakariyya Al-Kandahlawi. (2006). Himpunan Fadhilah Amal, Yogyakarta, Ash-Shaff.

Rixon, shelagh. (1999). Young Learners of English (Some Research Perspective). London, Longman.

Said mursi, S. M., (2001). Seni Mendidik Anak, Jakarta, Pustaka Al-Kautsar.

Sami, Abdus, at all,. (2010). Al-Qur'an Dengan Tajwid Blok Warna, Jakarta, Lautan Lestari. Steinberg, D. Danny, at all., (2001). Psycolinguistics, Malaysia, Pearson Education Limited.

Svecova, Hana. (2006). Basic for Children, China, Oxford University Press. 
Andi Irlina

Al-Adzka: Vol. 9, No. 1, Juni 2019 